Ann. Zootech., 1980, 29, no h. s., 189-196.

\title{
Physiological aspects of the regulation of food intake
}

\author{
J.M. FORBES \\ Department of Animal Physiology \& Nutrition, \\ University of Leeds, LS2 $9 J T(U K)$
}

\begin{abstract}
Pathways for the feed-back of information on the chemical and physical status of the gastro-intestinal tract and liver are summarised : rumen, duodenal and liver chemoreceptors, abdominal temperature receptors and gut stretch receptors. It is postulated that these signals are additive and are integrated in the hypothalamus with information from the higher brain concerning competing drives, the sensory qualities of the food available, and possible learned responses.

The likely sequence of events during a feeding cycle is described and experiments to provide answers to several paradoxes are indicated : the need to avoid supraphysiological rates of application of treatments; to offer a choice of feeds when investigating appetites, for example protein ; to avoid using simple statistical procedures to analyse a complex phenomenon.

In a discussion of practical considerations for beef production attention is drawn to possibilities for stimulating food intake ; for explaining the lower food intake observed with commercial modifiers of rumen fermentation; for predicting food intake.
\end{abstract}

\section{Résumé}

\section{Aspects physiologiques de la régulation de l'ingestion des aliments}

D'abord l'auteur présente un résumé des principales voies de transmission et de contrôle des informations concernant les caractéristiques physiques et chimiques du tube digestif et du foie liées au comportement alimentaire : le rumen, les chimiorécepteurs du duodénum et du foie, les thermorécepteurs abdominaux et les mécanorécepteurs du tube digestif. Il est admis que ces messages sont additifs et intégrés dans l'hypothalamus avec des informations venues du cerveau qui reçoit diverses directives liées par exemple aux qualités sensorielles des aliments offerts ou à un éventuel apprentissage alimentaire. La séquence probable des étapes successives d'un cycle d'alimentation est décrite. L'auteur indique certaines conclusions d'expériences qui permettent d'expliquer plusieurs paradoxes : nécessité d'éviter des niveaux supraphysiologiques dans l'application des traitements ; nécessité d'offrir un choix d'aliments, de protéines par exemple, quand on étudie l'appétit ; nécessité d'éviter l'emploi de méthodes statistiques simples pour analyser des phénomènes complexes.

Dans les considérations pratiques concernant la production de viande on s'intéresse aux possibilités de stimulation de l'ingestion, aux explications possibles de la diminution de la consommation sous l'effet d'additif alimentaire et à la prévision des quantités ingérées. 


\section{I. - Introduction}

Beef cattle have not been widely used for experimental work on the physiology of food intake regulation because of their expense and large size, when compared to sheep. Much of the material in this paper is, therefore, derived from work with sheep, and we must not forget the likely species differences which alter the relative importance of some of the factors to be discussed. I have used examples from cattle whenever possible.

In the free-feeding situation cattle eat in discrete meals, so that studies of factors affecting the daily intake, or the intake during a short period of access to food, are not always useful. On the other hand measurements of blond levels of metabolites and hormones, and of gut concentrations and flows of products of digestion, are not easy to make because of the unpredictable nature of meal occurence and the possibility that the taking of samples disrupts the animal's normal behaviour. The most useful method of study in pratice is, therefore infusion of a substance suspected of being involved in hunger or satiety and observation of its effects on feeding behaviour (see BAILE and Forbes, 1974).

\section{II. - Individual factors affecting food intake}

\section{A. - Products of digestion}

Infusion of volatile fatty acids (vfa) into the blood via the jugular vein (DowDEN and JACOBSON, 1960) or into the rumen (THOMAs et al., 1961) of cattle depressed intake, the latter giving a greater response, especially for acetate. It was later shown (BAILE and MAYER, 1969) that acetate was effective in depressing intake of sheep when infused only during spontaneous meals into the rumen, and that this was largely blocked by intraruminal treatment with anaesthetic (MARTIN and BAILE, 1972). The rate of intraruminal infusion necessary to cause a 50 per cent depression in daily intake (c. 150 mmoles per meal) results in a concentration of rumen acetate at the end of meals far greater than that occurring with physiological satiety, when rumen vfa levels have barely started to rise.

Infusion of propionate into the rumen of cattle also depresses food intake (MONTGOMERy et al., 1963), as does jugular vein infusion (DOWDEN and JACOBson, 1960). Since then, however, attention has been focused on the liver as the most likely site for propionate sensitivity. BAILE (1971) found the greatest effect when propionate was infused into the ruminal vein, compared with mesenteric vein, hepatic portal vein or carotid artery, but more recent work (BHATTACHARYA and Alulu, 1975 ; ANIL and Forbes, 1980) strengthens the view that the liver is the primary site of action of infused propionate. Specific denervation of the liver, by section of the hepatic plexus, was found to prevent the complete cessation of feeding which otherwise occured with a 3-hour infusion of 4 mmoles per minute of propionate into the portal vein (ANIL and FORBES, 1980). As with the effect of acetate noted above, the rate of infusion of propionate necessary to prevent feeding is greatly in excess of the rate at which propionate is being taken up from the rumen at the end of a meal. In cattle, CHASE et al. (1977) could detect no increase in portal levels of vfas by the time their animals stopped eating spontaneous meals, and the physiological significance of infusions of artificially large quantities must be in doubt. 
Butyrate has smaller effects on feeding than do acetate and propionate and is not likely to play an important role in the control of feeding.

The production of lactate occurs rapidly after the start of a meal (WALDo and SCHULTZ, 1956) and infusion of exogenous lactate into the rumen of cattle depressed food intake (BHATTACHARYA and WARNER, 1967) whereas there was no effect of intravenous infusion (DowDEN and JACOBSON, 1960). The explanation seems to be that the duodenum is sensitive to lactate, at least in sheep (BUENO, 1975) although, once again, the rate of duodenal infusion required to depress intake significantly is greater than the rate at which lactate normally appears during a spontaneous meal.

\section{B. - Physical fill}

The eff ects on roughage intake of distension of balloons in the rumen of cattle were discussed by CAMPLING (1970) who conciuded that, in general, the depression in intake is less than would be expected from a knowledge of the proportion of the rumen occupied by balloons. Addition of materials to, and removal of digesta from, the rumen have usually been followed by incomplete compensation in terms of voluntary food intake.

\section{C. - Temperature}

Exposure to high environmental temperatures causes a reduction of feed intake, the ruminant being especially sensitive because of the heat produced by fermentation in the rumen. Specific heating of the anterior hypothalamus of goats depressed food intake (ANDERSSON and LARSSON, 1961) as did heating of the rumen contents of cattle (GENGLER et al., 1970). Although the hypothalamic temperature of goats rose at the regular time of feeding, it did so even when food was not available (Dinius et al., 1970) ; conversely, intraruminal force-feeding of sheep did not resuit in a change of hypothalamic temperature (BAILE and MAYER, 1968). The lack of correlation between feeding and hypothalamic temperature need not mean that gut temperature changes are not involved in satiety ; the significance of peripheral temperature receptors in the integrated regulation of body temperature is now accepted.

This is by no means a complete catalogue of factors known to influence spontaneous feeding behaviour, but sufficient to emphasise the multifactorial nature of intake control. We will now discuss their integration into the overall control of feeding in ruminants.

\section{III. - Integration into a complete system}

\section{A. - Central nervous system}

So far, no mention has been made of the brain, which must undoubtedly play a central role in feeding. Each set of receptors is connected to the brain with projections eventually passing in the medial forebrain bundle through the lateral hypothalamus (LAMMERS and LOHMAN, 1974). Because the brain contains $10^{10}$ neurones some degree of simplification is necessary in trying to describe its functions. 
Figure 1 shows a simple nervous system in which the brain is represented as two "cells"! One receives visceral information on the extent of stimulation of chemoand mechanoreceptors (some receptors may have more than one property; LEEK and HARDING, 1975) and is roughly analogous to the hypothalamus. This lower cell also controls hormone secretion and gut motility and has numerous connections with the other cell, which is analogous to the higher centres of the brain. This second, higher, cell receives information from the special senses (although some of this information may go directly to the lower cell) and controls voluntary muscular movements, including those involved in ingestion. The higher cell also makes decisions on the priority of various drives (e.g. a hungry animal may drink if it is thirsty or eat if it is not thirsty; a cow may seek food when in dioestrus, but seek the bull when in oestrus) and may also modify the behaviour which would otherwise be induced by visceral signals, depending on what has been learned by previous experience.

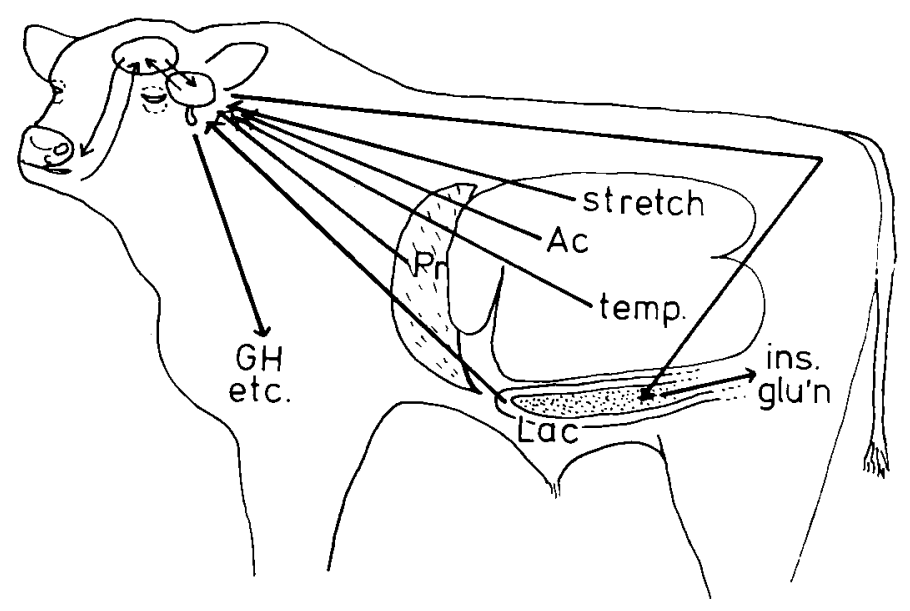

FIG. 1.

If we accept this simple picture as being a reasonable representation of the organisation of the nervous system, then we can see that the decision to start or stop feeding depends neither on the level of one metabolite in rumen fluid or in blood, nor on the total of all visceral signals, but on the balance between these visceral signals and the influences of attractiveness of food, competing drives and learned responses. It might appear from this that very complex experiments are necessary to unravel the physiology of intake control. We can, however, simplify things by keeping constant those factors which are under our control so that we normally keep experimental animals individually in a situation where the only drives which they can express are feeding and drinking; and we control the effect of palability and preference by offering a single feed without choice.

\section{B. - Description of a feeding cycle}

The changes occurring between the start of one spontaneous meal and the next meal, in a controlled, monotonous environment can be speculatively summarised as follows : 
The animal starts to eat at a rate determined by the physical and chemical properties of the feed, and as long as feeding continues the volume of rumen contents increases, progressively stimulating the stretch receptors in the rumen and reticulum walls. Within a few minutes of the ingestion of the first bite of the meal, soluble food constituents are starting to be fermented and rumen vfa concentrations slowly rise. The increase in muscular activity of the rumen brings some vfas from previous meals into contact with the rumen wall. Portal vein concentrations of acetate and propionate rise gradually and the uptake of propionate by the liver increases, possibly encouraged by the rise in insulin and glucagon secretion which accompanies feeding. The increased flow from the rumen carries lactate through the abomasum to the duodenum, to stimulate the duodenal receptors. As fermentation gets under way rumen temperature rises, stimulating receptors with afferent fibres in the splanchnic nerve (RAwson and Quick, 1971). The total effect of these stimuli may be enough to inhibit feeding ; additionally there may be a learned component to satiety (Воотн, 1972) a!though this has not been examined in ruminants.

After the end of the meal, fermentation and other digestive processes continue, and absorption of the products of the soluble fraction of the food reaches a peak. After this first peak there is a more prolonged peak of absorption from the fermentation and digestion of the insoluble part of meal. Whether or not the second phase of digestion is sufficient to maintain satiety depends on its magnitude relative to the energy requirements of the animal. During the inter-meal period the volume of rumen contents progressively declines and, eventually, so do the rumen acetate and duodenal lactate concentrations, the hepatic uptake of propionate, and rumen heat production. When the total of all the inhibitory signals to the brain has fallen below a critical threshold, feeding is once again initiated.

This cycle can be modified by external factors such as the availability of fresh food, the behaviour of adjacent animals or human disturbance.

\section{C. - Possible explanation of some paradoxes}

If the ideas expressed above are a reasonable, although grossly simplified, expression of the events involved in the control of feeding, we can see why experimental application of one stimulus requires supraphysiological levels in order to prevent feeding. It would be more realistic to apply two or more stimuli and we have preliminary evidence that the effects of infusing acetate into the rumen and propionate into the portal vein are additive (G.B. ADAMS and J.M. ForbeS, unpublished results). On the other hand, BhatTaCHARYA and WARnER (1968) found that propionate additions to the rumen partly alleviated the depression of intake caused by acetate.

Another paradox has been that, if feeding occurs in response to a deficit of available energy, why are observed meals neither regularly timed nor their size correlated with pre- or post-meal interval (BaILE, 1975a). Computer simulation of the scheme outlined above predicts irregular meal patterns, with no short-term relationships between meal frequency and meal size, because of the circadian variations in the animal's energy demand and the long period over which the products of digestion of each meal become available to the metabolic processes within the animal. Further perturbations are caused by extrinsic factors, as mentioned above.

Dietary deficiences of protein or non-protein nitrogen lead to low food intake, although the animal would have greater chances of survival if it were 
to eat more of a protein-deficient feed. In doing so it would, however, eat too much energy and it is quite clear that it is the intake of energy, as represented by energy-yielding metabolites, that is primarily being controlled. There have been no critical experiments in which a choice of protein-rich and protein-poor diets have been offered to ruminants in order to study the extent to which they can control their protein intake independently of their energy intake.

\section{IV. - Practical considerations for beef production}

\section{A. - Stimulation of food irtake}

Although it is possible to increase food intake spectacularly in the very short term by intracranial injections of various drugs in cattle and sheep (BAILE, $1975 b$ ), compensation follows and growth rates are not increased. At the peripheral level, anaesthetisation of some of the receptors involved in satiety may be of more use. Thus, the alleviation of the effects of intraruminal infusions of acetate by inclusion of local anaesthetics in the infusate has been followed by investigations of the effects of including such compounds in ruminants feeds. Elfazepam stimulates roughage intake and growth rate of cattle in a manner consistent with reducing the sensitivity of rumen stretch receptors (DinIUS and BAILE, 1977). There is less chance of stimulating the intake of feeds for which physical limitations are of lesser importantce. For example, a treatment which reduced the sensitivity of rumen acetate receptors would, presumably, allow larger meals but the subsequently greater effects of the other negative feed-backs from the larger meals would increase the inter-meal interval. Even if an increase in daily intake could be achieved, the extra energy would go to fat, as the requirements for growth were, presumably being met in the absence of treatment. It is important to reduce to a minimum external negative effects on feeding such as environmental stress, soiling of the feed and excessive competition for trough space.

\section{B. - Modification of rumen fermentation}

Substances such as monensin, which increase the production of propionate at the expense of methane and acetate, are usually associated with reduced food intakes, although growth rate and milk yield are unaffected and efficiency is therefore improved (e.g. Lemenager et al., 1978). Perhaps this indicates a more powerful role for liver propionate receptors compared with rumen acetate receptors. The reduction in turnover of rumen fluid and solid phases with monensin treatment might result in increased importance of rumen mechanoreceptors in limiting intake (LEMENAGER et al., 1978). The effect of monensin on roughage intake can be prevented by elfazepam (Dinius and BAILE, 1977) which is consistent with the proposed modes of actions of these drugs.

\section{C. - Predicting food intake}

There are two general approaches to predicting voluntary food intake of cattle. One is to calculate multiple regression coefficients from obseryed data, with intakes as the dependent variable and liveweight, feed digestibility, protein 
content etc. as independent variables. The resultant predictions are applicable to similar situations to those in which the data were collected but cannot be taken out of that context. It is not possible, for example, to obtain valid predictions for intakes of lactating cows from data obtained from mature wether sheep. Some modelling developments of the regression approach may appear at first sight to offer more useful predictions (Forbes, 1977; MonteIro, 1972) but are still constrained by the original relationships on which they are based.

The second approach is simulation modelling, where observations made at a different level of organisation are used to construct a model of those features of metabolism and digestion which are considered by the modeller to be of significance in the control of food intake. The construction of such a model for the ruminant is described elsewhere (Forbes, $1979 ; 1980 \mathrm{a}, \mathrm{b}$ ) : it is sufficient to say here that although the predicted food intakes are realistic, and respond sensibly to changes in the physiological status of the animal and the physical and chemical characteristics of the feed, it is not yet possible to predict intakes with sufficient accuracy to be useful in the formulation of diets for beef cattle.

\section{V. - Conclusions}

Our improving understanding of physiological mechanisms of hunger and satiety have not as yet yielded methods of consistently improving beef production, although the use of a mild anaesthetic shows promise of increasing roughage intake.

\section{References}

Andersson B., LARSON B., 1961. Influence of local temperature changes in the preoptic area and rostral hypothalamus on the regulation of food and water intake. Acta Physiol. Scand., 52, 75-89.

AnIL M.H., Forbes J.M., 1980. Feeding in sheep during intra-portal infusions of shortchain fatty acids and the effect of liver denervation. J. Physiol. (In press).

BAILE C.A., 1971. Metabolites as feed-backs for control of feed intake and receptor sites in goats and sheep. Physiol. and Behav., 7, 819-826.

BaILE C.A., 1975a. Control of feed intake in ruminants. In : Digestion and Metabolism in the Ruminant. Eds. I.W. McDonald and A.C.I. WARner, Univ. New England, Armidale, N.S.W. pp 333-350.

BaILE C.A., 1975b. Putative neurotransmitters in the hypothalamus and feeding. Fed. Proc., 33, 1166-1175.

Baile C.A., Forbes J.M., 1974. Control of feed intake and regulation of energy balance in ruminants. Physiol Rev., 160-214.

Baile C.A., Mayer J., 1968. Hypothalamic temperature and regulation of feed intake in goats. Am. J.. Physiol., 214, 677-684.

Baile C.A., MaYer J., 1969. Depression of feed intake of goats by metabolites injected during meals. Amer. J. Physiol., 217, 1830.

Bhattacharya A.N., Alulu M., 1975. Appetite and insulin-metabolite harmony in portal blood of sheep fed high or low roughage diet with or without intraruminal infusion of VFA. J. Anim. Sci., 41, 225-233.

BHATTACHARYA A.N., WARner R.G., 1967. Rumen $\mathrm{pH}$ as a factor for controlling feed intake in ruminants. $J$. Dairy Sci., 50, 1116-1119.

BhatTaCharya A.N., Warner R.G., 1968. Effect of propionate and citrate on depressed feed intake after intraruminal infusions of acetate in dairy cattle. $J$. Dairy Sci., 51, 1091-1094. 
Booth D.A. 1972. Conditional satiety in the rat. J. comp. physiol. Physchol., 81, 457-471.

Bueno L., 1975. Rôle de l'acide DI.-lactique dans le contrôle de l'ingestion alimentarre chez le mouton. Ann. Rech. Vet., 6, 325-336.

Campling R.C., 1970. Physical regulation of volontary intake. In : Physiology of Digestion ana Metabolism in the Ruminant. Ed. A.T. Phillipson. Oriel Press, Newcastle.

Chaje L.E., WangSness P.T., Martin R.J., 1977. Portal blood insulin and metabolite changes with spontaneous feeding in steers. J. Dairy Sci., 60, 410-415.

Dinius D.A., Baile C.A., 1977. Beef cattle responses to a feed intake stimulant given alone and in combination with a propionate enhancer and an anabolic steroid. J. Anim. Sci., 45, $147-153$.

Dinius D.A., Kavanaugh J.F., Baumgardt B.R., 1970. Regulation of food intake in ruminants. 7. Interrelations between food intake and body temperature. J. Dairy Sci., $53,438-445$.

DOWDEN D.R., JACOBSON D.R., 1960. Inhibition of appetite in dairy cattle by certain intermediate metabolites. Nature, London, 188, 148-149.

Forbes J.Mi., 1977. Development of a model of voluntary food intake and energy balance in lactating dairy cows. Anim. Prod., 24, 203-204.

Forbes J.M., 1979. A model of the control of food intake in ruminants. EAAP 30th Annual Metting, Harrogate, Yorkshire.

Forbes J.M., 1980a. Hormones and metabolites in the control of food intake. Proc. Vth Int. Symp. Ruminant Physiology. Ed. Y. RUCKEBUSCH and P. THIVEND. MTP, Lancaster.

Forbes J.M., 1980 $b$. A model of the short-term control of feeding in the ruminant. Effects of changing animal or feed characteristics. Appetite, 1, 21-41.

Gengler W.R., Martz F.A., Johnson H.D., Krause G.F., Hahn L., 1970. Effect of temperature on food and water intake and rumen fermentation. J. Dairy Sci., 53, 434-437.

Lammers H.J., Lohman A.H.M., 1974. Structure and fibre connections of the hypothalamus in mammals. Progress ini Brain Research, 41, 61-78.

LEeK B.F., Harding R.H., 1975. Sensory nervous receptors in the ruminant stomach and the reflex control of reticulo-ruminal motility. In : Digestion and Metabolism in the Ruminant. Ed. I.W. MCDonald and A.C.I. Warner, Univ. New England, Armidale, NSW.

Lemenager R.P., Owens F.N., Lusby K.S., Totusek R., 1978. Monensin, forage intake and lactation of beef cows. J. Anim. Sci., 47, 247-254.

Lemenager R.P., Owens F.N., Shockley B.J., Lusby K.S., Totusek R., 1978. Monensin effects on rumen turnover rate, twenty-four hour VFA pattern, nitrogen components and cellulose disappearance. J. Anim. Sci., 47, 255-261.

MARTIN F.H., BAILE C.A., 1972. Feed intake in goats and sheep following acetate or propionate injections into rumen, ruminal pounches, and abomasum as affected by local anaesthetics. J. Dairy Sci., 55, 606-613.

Monteiro L.S., 1972. The control of appetite in lactating cows. Anim. Prod., 14, 263-282.

Montgomery M.J., Schultz L.H., Baumgardt B.R., 1963. Effect of intraruminal infusion of volatile fatty acids and lactic acid on voluntary hay intake. J. Dairy Sci., 46, 1380-1384.

Rawson R.O., Quick K.P., 1971. Unilateral splanchnotomy : its effect on the response to initra-abdominal heating in ithe ewe. Pflugers Arch., 330, 362-365.

Thomas J.W., Moore L.A., OKamoto M., Sykes J.F., 1961. A study of factors affecting rate of intake of heifers fed silage. J. Dairy Sci., 44, 1471-1483.

Waldo D.R., Schultz L.H., 1965. Lactic acid production in the rumen. J. Dairy Sci., 39, 1453-1460. 